\title{
A GEOGRAPHICAL APPRAISAL OF THE SOVIET FOREST RESOURCE
}

\author{
BY ROBERT M. BONE
}

Robert M. Bone, Hon. B.A. (U.B.C.), M.A. (University of Washington), Ph.D. (University of Nebraska), is a geographer specializing in Soviet resource development. Since 1963, he has held the position of assistant professor of geography at the University of Saskatchewan. From 1959 to 1963, Dr. Bone was employed in the Geographical Branch of the federal government. He has published a number of articles on the Soviet Union.

\section{ABSTRACT}

The presence of a vast forest represents a valuable natural asset to any nation. In the case of the Soviet Union, the harnessing of this resource greatly facilitated its economic development. The particular distribution of forest has resulted in certain regional problems and trends. Presently there is a shift of logging and a slow but gradual migration of associated processing industries northward and eastward from the traditional logging region of central European Soviet Russia. The new emphasis on expanding the wood and paper fabricating industries reflects the growing sophistication of this Soviet industry. Not withstanding the recognized potential of this segment of the Soviet forest industry, there are presently certain shortages of wood and paper products.

The forest of the Soviet Union is one of its major resources. The enormous size and economic potential of this natural asset is best appreciated by viewing the world scene. According to the United Nation's statistics, the U.S.S.R., contaning $20 \%{ }^{1}$ of the world's forest lands, has the largest forested area of any country in the world. Furthermore, about $1 / 3$ of the world's utilized forest and growing stock falls within the territorial limits of the U.S.S.R. ${ }^{2}$ The theme of this paper is to briefly appraise this vital resource, its utilization and its significance to the Soviet economy.

The Development and Characteristics of the Soviet Forest Industry

During Soviet rule, the expansion of logging and the growth of the processing and manufacturing segment of the forest industry has been most remarkable. Industrial wood production, commonly thought of as commercial timber, has increased from around 50 million cubic meters in the late 1920's to over 250 million cubic meters in the early 1960 's. ${ }^{3}$ By 1965 , this output should reach nearly 280 million cubic meters, which will probably account for slightly over $25 \%$ of world production. The flow of lumber, paper, plywood, and other forest products from Soviet factories, while starting 
from an initially low level, has grown considerably. Presently, industrial wood and lumber output forms about $1 / 4$ of the world's production while highly processed goods, such as paper products, generally comprise less than $5 \%$ of world production. This gap between the basic stages of wood utilization and the more sophisticated manufacturing stages, while slowly narrowing in recent years, represents to some degree, the pattern of development of Soviet industry.

Traditionally, the forest has satisfied a considerable portion of Russia's fuel needs. While the present consumption of firewood is approximately triple that of Tsarist Russia, there has been a relative decline in the utilization of firewood. In 1913, over half of all timber cut served as firewood, constituting $20 \%$ of the national fuel budget. Today, about $1 / 4$ of the timber cut is used as firewood, satisfying about $4 \%$ of Soviet fuel requirements. ${ }^{4}$ With the ever increasing substitution of mineral fuels for firewood, this pattern of timber consumption will likely continue to decline. Clearly, this single resource shift marks not only the U.S.S.R.'s march from a somewhat backward country to one of the world's economic giants but also reveals signs of the unequal economic advancement of the various segments of the Soviet economy and society.

\section{The Pattern of Forest Exports and Imports}

In international trade, the presence of Soviet forest products is well established. Historically, the bulk of forest exports from both the Russian Empire and the U.S.S.R. have undergone little processing while most of its imports have received considerable processing, such as paper products. More recently, Soviet exports revealed two trends. First of all, the traditional exports of round wood and lumber have expanded enormously. By 1962, the volume of exports of round wood and sawn wood exceeded the 1913 level, which, for nearly fifty years probably represented the maximum annual export of these two commodities. Secondly, the introduction of new exports, such as wood pulp, and the expansion of other processed goods, such as plywood, reflect the gradual maturing nature of this nation's forest production. Presently, however, the volume of Soviet imports of fabricated wood and paper products almost matches its exports. During the Seven Year Plan (1959-1965), vast sums of capital have been invested into the manufacturing sector of this industry. By the late 1960's, this investment program will likely result in a sharp expansion of exports of processed and manufactured wood products as well as a virtual cessation of imports. The ability of Soviet fabricated products to successfully enter non-captured markets, such as those of western Europe, will depend upon price, quality, suitability and/or adaptability for local markets and satisfactory delivery in terms of both time and condition of goods. With these conditions satisfied, in the 1970's, the Soviets may, in terms of value, earn most of their foreign forest revenues from finished goods. Nevertheless, there presently exists critical shortages of certain wood, cardboard, and paper products.

Forest exports, which have always greatly exceeded imports, are an important source of foreign currencies. In the industrialization period of the 1930 's, the foreign earnings obtained through the sale of forest products, con- 
sisting almost entirely of round wood and lumber, were of considerable importance, permitting the purchase of western capital goods desperately needed to facilitate the success of various industrial programs. In fact, without these export revenues, many of these programs may have been seriously delayed.5 In recent years, the significance of forest exports has not escaped Soviet attention. In early 1964, former Premier Khruschev announced that on the basis of the planned expansion of the processing and manufacturing sector of the forest industry, the value of exports could easily be increased from slightly less than $\$ 400$ million dollars to over half a billion dollars. ${ }^{6}$ Presently, timber ranks with gold and petroleum as major sources of western funds derived from essentially raw material exports. In today's world, the government of the U.S.S.R. requires vast sums of foreign monies not only to engage in international trade, but also to facilitate their extensive loan and aid programs to many emerging nations of Africa, Asia, and Latin America.

\section{Distribution of Forest and Its Pattern of Utilization}

The distribution of forest land in the Soviet Union is far from ubiquitous. While about $1 / 3$ of the U.S.S.R. is covered by forest, east of the Ural Mountains over $70 \%$ of the forest lands are found (Table 1 and Figure 1). Indeed, almost half of the nation's forest is in the economic region of East Siberia. By contrast, vast areas of the Soviet Union have only meager forest resources. Soviet Central Asia has only $1 \%$ of the forest area of the entire country while the Trans Caucasian Economic Region has but $1 / 2 \%$. The Central Industrial Region, which has long been considered one of the most important logging areas of the nation, contains only slightly more than $2 \%$ of the national forest land. These regional inequalities in forest distribution with respect to the main consumption area of European Soviet Russia has created some resource development difficulties-intense exploitation of western forest and weak utilization of Siberian forest.

The main forest belt, containing about $90 \%$ of the forest of Russia, stretches across northern European Russia and occupies most of Siberia (Figure 2). Within this vast zone, nearly all the logging takes place. Generally, the forest belt of the Northwest and Ural political entities lies south of the Arctic Circle while in East Siberia, it lies south of the 70th parallel. In the Far East, mountain tundra predominates over most of the territory north of the 60th parallel.

Within this belt, the percentage of forest area to total area while varying from region to region is generally above $50 \%$. In the Soviet portion of European Russia, the percentage of forest area varies greatly. The Lithuanian Republic, the Murmansk Oblast, and the Komi Autonomuos Republic have $24 \%, 31 \%$ and $67 \%$ of their area occupied by forest respectively. ${ }^{7}$ In the Urals and Siberia, the variation of forest cover within the forest belt ranges from $76 \%$ in the Irkutsk Oblast, $63 \%$ in the Sverdlovsk Oblast, $54 \%$ in the Khabarovsk Kray, and about $40 \%$ in West Siberia. ${ }^{8}$ While the vast forest zone between the steppe and the tundra is a potential logging area, most timber cutting has been concentrated west of the Ural Mountains. Furthermore, while in European Soviet Russia intensive logging actvities occur near the Arctic Circle, in Siberia, most of this work takes place much further south. 
TABLE 1

Regional Percentages of Forested Area, Industrial Wood, and Lumber

\begin{tabular}{lccc}
\hline Economic Regions & $\begin{array}{c}\text { Forested } \text { Area }^{2} \\
(\mathbf{1 9 6 1 )}\end{array}$ & $\begin{array}{c}\text { Industrial Wooda } \\
(\mathbf{1 9 6 2 )}\end{array}$ & $\begin{array}{c}\text { Lumber" } \\
(\mathbf{1 9 6 2 )}\end{array}$ \\
\hline Northwest & 10.58 & 25.5 & 16.5 \\
Central Industrial & 2.26 & 6.6 & 8.7 \\
Volga-Vyatka & 1.63 & 8.8 & 7.6 \\
Central Chernozem & 0.20 & 0.3 & 1.2 \\
TransVolga & 0.60 & 1.5 & 5.7 \\
Northern Caucasus & 0.48 & 1.2 & 2.6 \\
Ural & 10.38 & 20.5 & 14.7 \\
West Siberia & 4.89 & 5.7 & 6.2 \\
East Siberia & 46.81 & 16.0 & 12.8 \\
Far East & 16.41 & 5.6 & 4.4 \\
Ukraine-Moldavia & 1.02 & 3.8 & 9.5 \\
Belorussia & 0.91 & 1.9 & 2.7 \\
Baltic & 0.69 & 1.8 & 2.7 \\
Transcaucasus & 0.49 & 0.2 & 1.2 \\
Kazakh & 1.49 & 0.5 & 2.5 \\
Central Asia & 1.16 & 0.1 & 1.0 \\
& 100.0 & 100.0 & 100.0 \\
\hline
\end{tabular}

${ }^{1}$ The Ukraine and Moldavian Republics are artificially grouped together owing to the facts that they are territorially contiguous and both have minor forested areas and wood production.

${ }^{2}$ Forested area refers to land actually covered by trees and totals 738.1 million hectares; the 1962 industrial wood and lumber outputs were 255.7 million cubic meters and 104.6 million cubic meters respectively.

Sources: Narodnoe Kbozyaystvo SSSR 1961 g., p. 232 : Narodnoe Kbozyaystvo SSSR v. 1962 g., pp. 180-182; and Narodnoe Kbozyaystvo RSFSR $\nu 1962$ godu, PP. 92-98.

Generally, this tendency increases towards the Pacific Coast. While in West Siberia and East Siberia, some large scale logging camps are situated near the 60 th parallel, in the Far East, only an inconsequential amount of cutting occurs north of the 55th parallel. The present general absence of logging in certain northern areas of Siberia reflects difficulties of access and severe natural conditions, including the presence of extremely long cold winters and permafrost as well as the more attractive alternate of tapping the forest resources of southern Siberia, such as the Angara Basin, at considerably lower cost.

Within the main forest belt, which accounts for slightly over $97 \%$ of the industrial wood output, nearly half of the timber cutting occurs in European Soviet Russia, about $20 \%$ in The Ural Economic Region, and nearly $30 \%$ in Siberia. While the remaining production is scattered over a wide area, most of this logging is concentrated in the western portions of the Georgian Republic and the Krasnodar Kray. Separated from the main forest belt by the steppe zone, timber extraction in these two political units is based essentially upon the forest resource of the Caucasian Mountains. In 1962, this region accounted for nearly $11 / 2 \%$ of the commercial wood output of the Soviet Union. 


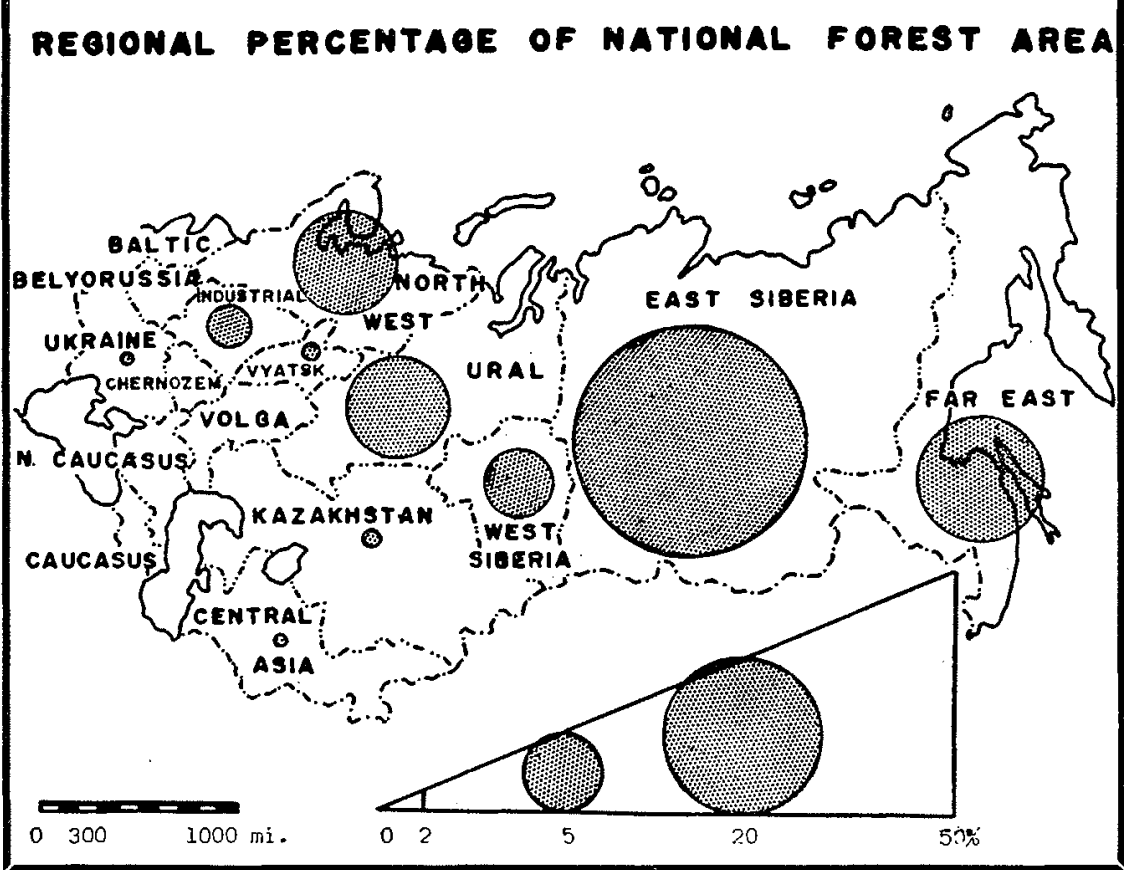

FIGURE 1. Regional Percentage of Forest Area, 1961. Adapted from Table 1.

The crux of the present policy of forest exploitation recognizes this pattern of forest distribution. Consequently, maximum efforts have been taken in the current Seven Year Plan to expand logging operations in the regions with large wood reserves and to reduce cuttings in the traditional logging areas (a comparison of figures 1 and 2 reveals this relationship). In general, logging is to be intensified in the northern and eastern areas of the Russian Federated Socialist Republic. At the same time, logging in central European Soviet Russia is to be slightly reduced.

The Major Commercial Timber Logging Zones

Within the forest belt, there are two major logging zones, which account for nearly $2 / 3$ of the Soviet industrial wood production, a secondary logging zone, which accounts for about $1 / 3$ of the commercial timber, and a "nonlogging" area, which occupies much of northern Siberia and the parkland belt of the forest zone. The western zone consists of the northern sector of the forested area of European Russia and most of the forested area of The Ural Economic Region. In 1962, this territory, with about $15 \%$ of the wood reserves of the nation, accounted for about half of the output. Since the bulk of these reserves are in The Northwest and Ural Economic Regions, expansion will likely occur in these areas. In the past, logging activities have been most intense along the southern fringe of the western zone and 


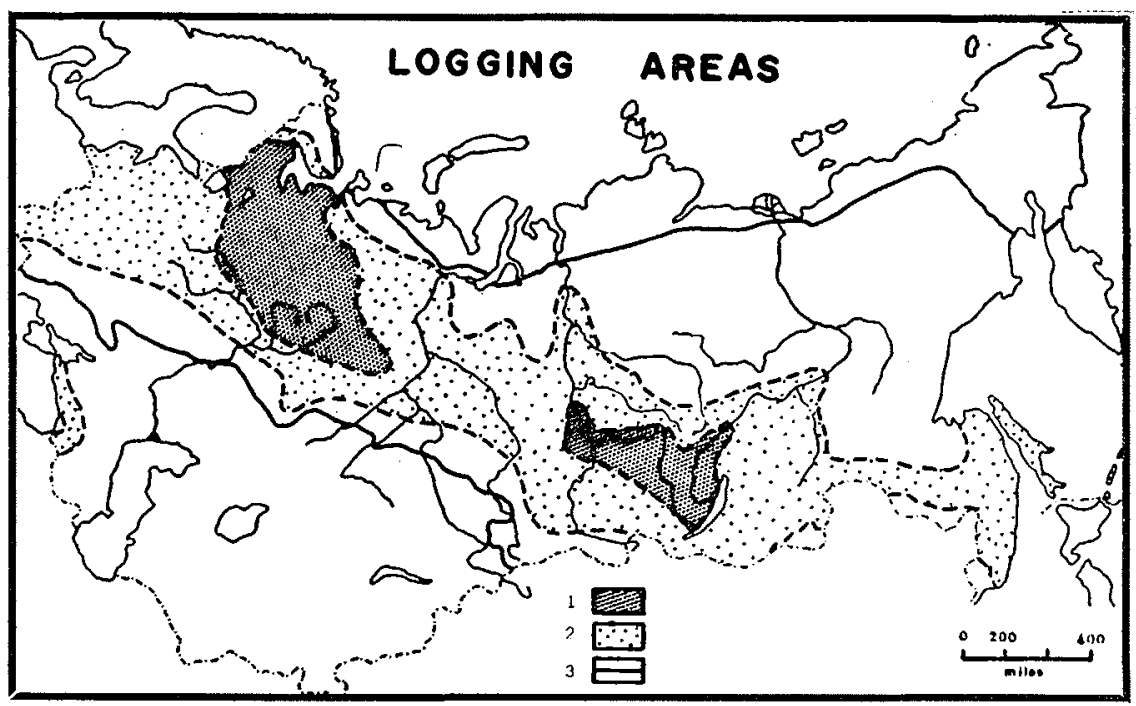

FIGURE 2. Logging Areas, 1962. Adapted from Table I and Narodnoe Kbozyaystvo RSFSR $v$ 1962 godu, pp. 92-95. Intensive logging operations are widespread in zone I which consists of the western and eastern logging zones. The western zone extends from the Northwest Region to the Ural Region while the eastern zone extends from the the West Siberian Region to the southern portion of the East Siberian Region. In zone 2 , timber cutting occurs but on a much smaller scale owing to either limited forest resources or to problems of access. The former limitation is generally associated with southern areas while the latter one with northern areas. In most of the subarctic areas of Siberia, the limited small-scale logging activities essentially supplies local communities and industries with firewood and lumber. Even so, many types of wood building materials are imported into this area. The limits of the main forest belt are indicated by symbol 3. The forest of the western Caucasian Mountains represents the only large utilized forested area outside of the main forest belt.

along key transportation routes. In the last few years, the Soviets, realizing the need for improved forest management in this region have modestly expanded their reforestation programs. ${ }^{9}$ These programs coupled with a decline in logging operations may result in the partial restoration of the presently meager wood resources of these severely exploited lands.

The eastern zone consists of the Tomsk Oblast, the southern extremities of the Krasnoyarsk Kray and most of the Irkutsk Oblast. Presently, logging activities are concentrated in the $\mathrm{Ob}$ Basin of the Tomsk Oblast, the Angara-Yenisei Basin and the upper reaches of the Lena River in the Irkutsk Oblast. In recent years, logging has greatly increased in the eastern zone. In 1940, this region accounted for less than 15 million cubic meters of industrial wood while, in 1962 , production has soared to nearly 40 million cubic meters. Nature, having endowed this region with nearly half of the wood reserves of the nation, has assured this zone's logging industry of an important position. In 1962, approximately $1 / 6$ of the national output came from this area. By the end of this decade, its production will likely rise to $20 \%$ of the national output. With such a rich resource base, the eastern 
logging region will probably someday become the leading logging area in the Soviet Union.

\section{CONCLUSION}

The forest resource has played a formidable role in the creation of one of the world's most powerful states. Over the last forty years, the exceptional rise in the consumption of industrial wood is an integrated link in this nation's remarkable transformation from a predominantly agricultural nation into a modern industrial state. The recent diversification of production, which has been achieved through massive capital investment, reflects the gradual maturing nature of this sector of the Soviet economy. The wide range of forest products now produced is found only in a few other nations which are both highly industrialized and endowed with a sizeable forest. While there is still a need to expand the processing and manufacturing branches of this industry to satisfy domestic shortages, within the next twenty years the Soviet Union should produce sizeable surpluses of most forest products, which will then be available for the export market of the world. At this time, it is entirely possible that the Soviet Union will not only be the world's leading producer of most types of forest products but also the world's leading exporter of these commodities. ${ }^{10}$

\section{Notes}

1 "Estimates of the World's Forest Resources", Unasylva, Vol. 16 (3), No. 66 (1962), p. 123. I lbid, p. 123.

${ }^{3}$ Narodnoe Kbozyaystvo SSSR $v 1962 \mathrm{~g}$, p. 142. Firewood, comprising about one quarter of all timber cut, is excluded from this term. These statistics refer only to agencies operating within the auspicious of the central plan. The output of several minor logging concerns including collective farms are excluded from these figures. The commercial timber output of these concerns probably amounts to less than $10 \%$ of the total production.

'Ibid., p. 152. In 1963, 370 million cubic meters of timber was cut of which 102 million cubic meters was used as firewood. Narodnoe Kbozyaystvo SSSR $\nu .1963$ g., p. 173.

"Acccrding to Elchibegoff, timber exports from 1922 to 1937 earned at least $1 \mathrm{Y} / 2$ billion roubles in hard foreign currencies. M. Elchibegoff, "U.S.S.R. International Timber Trade", Journal of Forestry, Vol. 59, No. 10 (October 1961), p. 759.

- "Khrushchev's Speech to Conference on Agriculture", The Current Digest of the Soviet Press, Vol. XVI, No. 10 (April 1, 1964), p. 24. The United Nations placed the 1961 value of Soviet forest exports at nearly $\$ 360$ million (U.S.) and its imports at approximately $\$ 100$ million (U.S.). United Nations, F.A.O., Yearbook of Forest Products Statistics, 1962, Tables 39 and 40.

"A. D. Ponomarev, "Lesnoy font SSSR", Lesnoe Kbozyaystvo, 6 (1963), p. 49.

${ }^{8}$ Ibid., p. 49.

The planned sowing and planting of seedlings is supposedly to increase from 610 thousand hectares in 1957 to 744 thousand in 1965. P. V. Vasilyev, "Prospects For Industrial Consumption of Wood And For Development of Forest Economy in USSR Under Seven-Year Plan, 1959-1965', Journal of Forestry, Vol. 57, No. 11 (Nov. 1959), pp. 818-821.

${ }^{10}$ In two Canadian publications, articles have recently appeared on the subject of the Soviet forest industry. Both of these articles represent scholarly work and will provide the reader with a fuller understanding of this Soviet resource and industry. Jan J. Solecki, "Forest Resources and Their Exploitation in the U.S.S.R.", The Forestry Chonicle, Vol. 39 (1963), pp. 212-223; and Jaroslaw Holowacz, "Organization, Production and Development of the Soviet Forest Industry", Pulp and Paper Magazine of Canada, (August, 1963), feature section. 